\title{
Full mouth rehabilitation with iliac bone graft for a patient with traumatic neuroma in mandible
}

\author{
Hyeran Kim¹, Jin-Ho Shin², Hong-Seo Yang ${ }^{1}$, Chan Park', and Hyun-Pil Lim ${ }^{1}$. \\ ${ }^{1}$ Department of Prosthodontics, School of Dentistry, Chonnam National University, Gwangju 61186, Republic of Korea \\ ${ }^{2}$ Design Dental Cilinic, Gwangju 61726, Republic of Korea
}

(Received Feb 1, 2017; Revised version received Mar 8, 2017; Accepted Mar 8, 2017)

\begin{abstract}
Damaged sensory nerves in the facial area might show spontaneous recovery. However, imperfect regeneration, such as paresthesia, numbness, and painful pathologic regeneration can occur in some cases. Therefore, iatrogenic nerve damage should be avoided during implant placement in patients with alveolar bone atrophy. For placement of implants in the posterior area of the mandible, the corresponding anatomical structures including the inferior alveolar nerve are of concern. Herein, we presented a case of a patient who developed traumatic neuroma after undergoing full mouth rehabilitation with implants in another hospital. Treatment at our facility included the removal of all implants posterior to the mental foramen, followed by an autogenous iliac bone graft performed on the atrophied alveolar ridge of the mandible. Subsequently, implants were placed in the grafted sites. Finally, the patient showed functional and esthetic results.
\end{abstract}

KEY WORDS: Iliac bone graft, Traumatic neuroma, Atrophic mandible, Full mouth rehabilitation, Implant

\section{서 론}

하악에 임플란트 식립 시 구치부 가용골의 높이는 하치 조신경에 의해 범위가 제한된다[1]. 안전영역이란 신경 혈 관 다발을 침범하지 않고 임플란트를 안전하게 지지할 수 있는 골 안의 부분으로 정의되는데, 하치조신경의 경우 안 전영역이 하악관 상방 약 $2 \mathrm{~mm}$ 이다[2]. 하지만 임플란트 매식시 신경 손상 가능성을 배제 할 수는 없으며, 삼차신 경과 이 신경의 분지들이 손상 받을 경우 환자들은 발음, 저작 및 사회적 관계의 불편감을 겪게 된다.

대부분의 감각 손상은 자연적인 회복 과정을 겪을 수 있 으나, 가벼운 감각저하(hypoesthesia)에서 보다 심각한 감 각이상(paresthesia)까지 반영구적인 손상이 다양하게 나타 날 수 있다[3]. 손상된 신경의 중심지와 원위부 사이에 이 물장벽이 있어 성공적인 신경재생이 어려울 경우 신경이 그 장벽에서 계속 증식하여 외상성 신경종(traumatic

*Corresponding author: Hyun-Pil Lim

Department of Prosthodontics, School of Dentistry, Chonnam National University, 33 Yongbong-ro, Buk-gu, Gwangju 61186, Republic of Korea Tel.: +82-62-530-5638, Fax: +82-62-530-5639

E-mail: mcnihil@chonnam.ac.kr neuroma)을 형성하게 된다. 외상성 신경종은 적절히 성장 하거나 수초형성을 못하므로 이를 자극하면 심한 동통과 감각이상이 초래된다[4].

악안면영역의 신경학적 문제들은 매우 다양해서 외상성 신경손상으로 인한 동통이 있는 경우 운동신경계, 자율신 경계, 감각신경계 모두가 관련성을 가지므로 약물치료와 수술적 치료 등을 동반하는 것이 필요하다. 외과적 시술로 는 감압법, 신경문합법, 이식술 등이 고려될 수 있다.

본 증례는 타 병원에서 하악에 임플란트를 식립한 후 외 상성 신경종이 발생한 환자에서 원인이 된 임플란트를 제 거하고, 위축된 하악골에 자가장골 온레이 형태로 이식을 한 후 임플란트로 전악 수복하여 만족할 만한 결과를 얻 었다.

\section{증례보고}

본 증례의 환자는 53 세 여환으로 타 병원에서 약 4 개월 전 전악 임플란트 매식 및 보철 후 생긴 하악의 동통을 주 소로 본원 응급실을 내원하였다. 내원 시 상악 양측 견치 를 제외하고 상하악 모두 전악 임플란트 보철 상태였다 (Fig. 1). 환자는 $\mathrm{C}$ 형 간염으로 정기적으로 의과적 치료를 


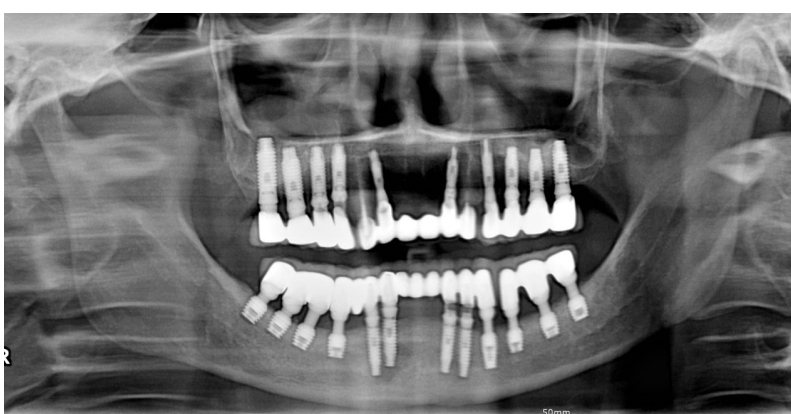

Fig. 1. Panoramic view at initial visit.

받고 있었고, 그 밖의 특이할 만한 의과적 병력은 없었다. 임상 검사상 턱과 이순구 부근의 부종과 심한 동통과 감 각이상이 확인 되었고, 최대개구량은 약 $30 \mathrm{~mm}$ 였으며, 구 내 하악 우측 이공 부근에 결절상 치은 증식이 관찰 되었 다. 이신경을 차단하자 통증이 경감되어 환자의 임상증상 과 임플란트 식립 후 발생했다는 점을 토대로 임플란트 식 립시 발생한 삼차신경의 외상성 신경종으로 진단하였다. 이후 환자는 통증이 계속되자 거리상의 문제로 식립한 병 원에 내원하여 $\# 42,43,44,45,46$ 임플란트를 제거하였고, 그 상태로 본원 구강외과에 다시 내원하였다(Fig. 2). 하악 우 측 임플란트 제거 후 바늘로 찌르는 듯한 통증은 호전되 었으나 여전히 턱 끝의 이상감각 등을 호소하여 남아 있 는 하악 좌측의 신경 또한 손상되었다고 판단하고 하악 좌 측 이공 후방의 \#34,35,36,37 임플란트와 \#47 임플란트를 제거하고 하악에 자가장골 이식을 시행하였다(Fig. 3).

환자는 자가장골 이식 후 하악 임시의치 제작을 위하여

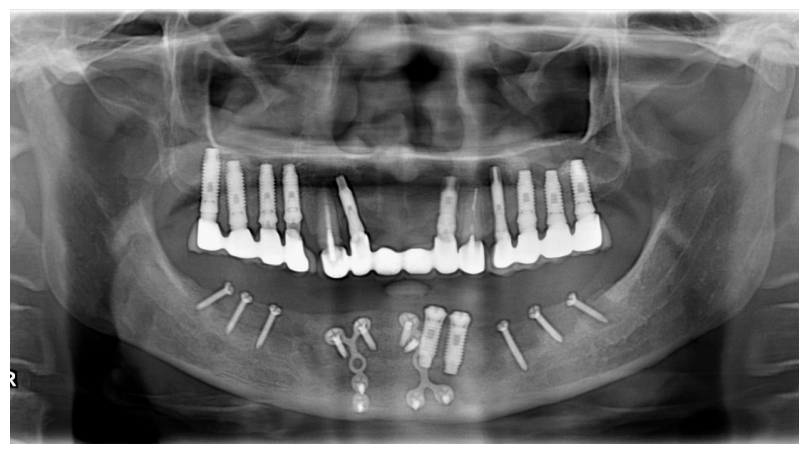

Fig. 3. Panoramic view after iliac bone graft of mandible.

본과에 의뢰되었고, 자가장골 이식 4 개월 후 임시의치를 복제해 제작한 방사선 스텐트(radiographic stent)를 착용하 고 촬영한 $\mathrm{CT}$ 와 진단모형을 분석해 임플란트 식립 부위, 개수, 직경과 길이 등을 선정해 1 차 수술을 시행하였다 (Fig. 4). 1차 수술 일에 먼저 장골 이식시 고정했던 금속 판과 금속핀을 제거하였고, 상악에 남아 있던 \#13, 23 또 한 2차우식으로 인해 발거와 동시에 즉시 식립하였다.

4개월 후 위축된 골과 함께 부족했던 연조직에 대한 치 료를 병행하기로 하여 구개 점막 이식을 이용한 전정성형 술과 임플란트 2차 수술을 시행하였다(Fig. 5). 감각 이상 의 직접적 원인은 아니나 교합평면 부조화로 발생할 비정 상적 측방압 등을 배제해 이식한 장골의 흡수를 줄이고 임 플란트에 위해한 외력을 최소화 할 수 있도록 상악의 임 플란트 보철도 모두 다시 하기로 하였다. 2 차 수술 1 개월 후 본과에서 개인트레이 제작을 위해 알지네이트로 상하 악 인상을 채득하고, 임플란트 고정체에 임플란트 코핑을

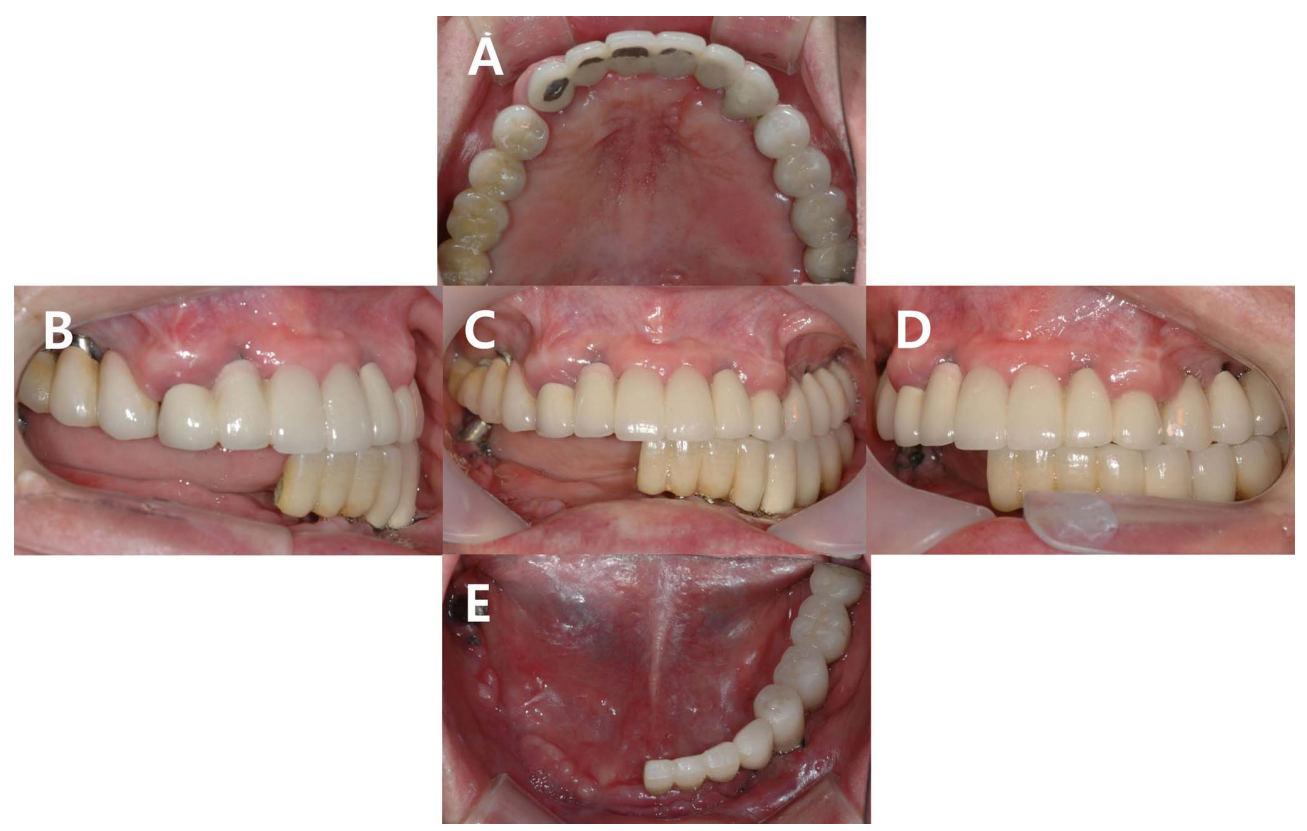

Fig. 2. Introral photo after removal of $\# 42,43,44,45,46$ implant. (A) Maxillary occlusal view, (B) Right buccal view during centric occlusion, (C) Frontal view during centric occlusion, (D) Left buccal view during centric occlusion, (E) Mandibular occlusal view. 


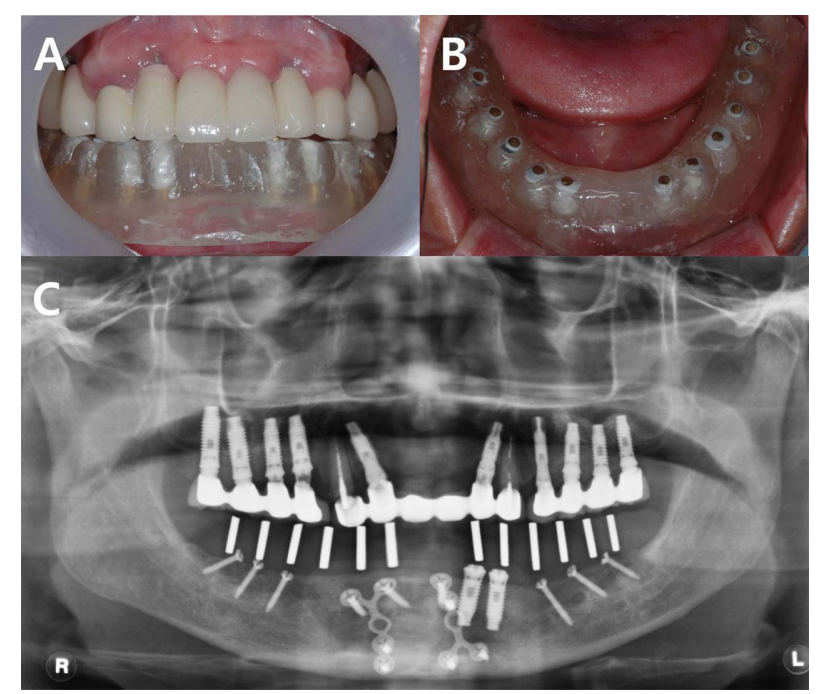

Fig. 4. (A) Frontal view during centric occlusion wearing radiographic stent on mandible, (B) Mandibular occlusal view, (C) Panoramic view with radiographic stent on.

연결한 후 폴리비닐실록산 인상재(Honigum ${ }^{\circledR}$ Mono, Light, DMG, Hamburg, Germany)로 pick up 인상 채득해 주모형 을 제작하였다.

상악의 경우 PTV(Periotest value) 결과가 불량하여 치유 지대주 상태로 더 지켜 보기로 하였고, 하악은 부착치은을 더 증강시키기 위해 치근단변위판막술을 추가적으로 시행 하였다. 양손 조작법과 Willis method로 중심위, 수직고경 을 결정하고, 안궁 이전하여 반조설성 교합기에 마운팅해
하악 \#33,34,42,45 임플란트의 CAD/CAM 맞춤 지대주와 임 시보철을 제작했다(Fig. 6). 하악 임시보철의 경우 치주 수술 후 치유를 도울 수 있는 형태로 제작하였다. 치근단변위판막 술을 시행한지 1개월 후 상악과 나머지 하악 임플란트에 대 한 pick up인상을 채득해 주모형을 제작하고 중심위와 수직 고경 결정 및 안궁 이전을 시행하였다. 과두 경로에 따른 전 치 유도로 및 교두각도를 조절하여 전방, 측방 운동시 구치 를 이개하여 중심위와 편심위 모두에서 이상적인 교합을 형 성할 수 있도록 Hobo가 제시한 twin-stage method대로 왁스 업을 시행하였다(Fig. 7)[5,6]. 왁스업 모형을 double scanning 하여 $\mathrm{CAD} / \mathrm{CAM}$ 맞춤 지대주와 임시치아(PMMA disk, Yamahachi, Gamagori, Japan)를 제작했다(Fig. 8).

1 개월 간 임시치아 상태에서 환자의 적응을 평가 한 후 교차마운팅을 위한 바이트를 채득하고 지대주 레벨에서 인상 채득하여 교합기에 교차마운팅 하였다(Fig. 9). 지르 코니아 코핑을 구내에 시적해 본 후 단일구조지르코니아 구조물(Prettau ${ }^{\circledR}$, Zirconia, zirkonzahn, Bruneck, Italy)에 Porcelain veneering(Cerabien ZR, Noritake, Nagoya, Japan) 하여 환자 구내에 최종 보철물을 장착하였다(Fig. 10). 좌 우측 균일한 교합이 이루어지며, 견치 유도가 됨을 확인하 였다.

이식골의 흡수를 대비하여 과잉된 량을 이식하였음에도 불구하고 식립 후 파노라마 사진 상에서 우측 구치부에 약 간의 골 소실이 관찰되었다. 하지만 초진 내원 시에 비해 통증이 많이 개선되었으며 그 밖의 저작, 발음 등의 기능 과 심미 모두에서 만족할 만한 결과를 얻었다(Fig. 11).

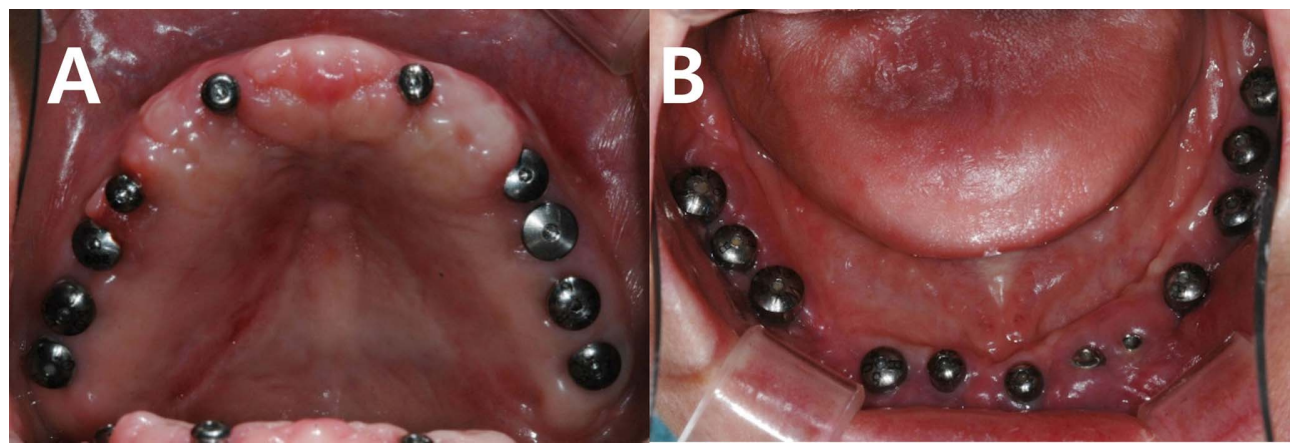

Fig. 5. Intraoral photo after 2nd surgery. (A) Maxillary occlusal view, (B) Madibular occlusal view.

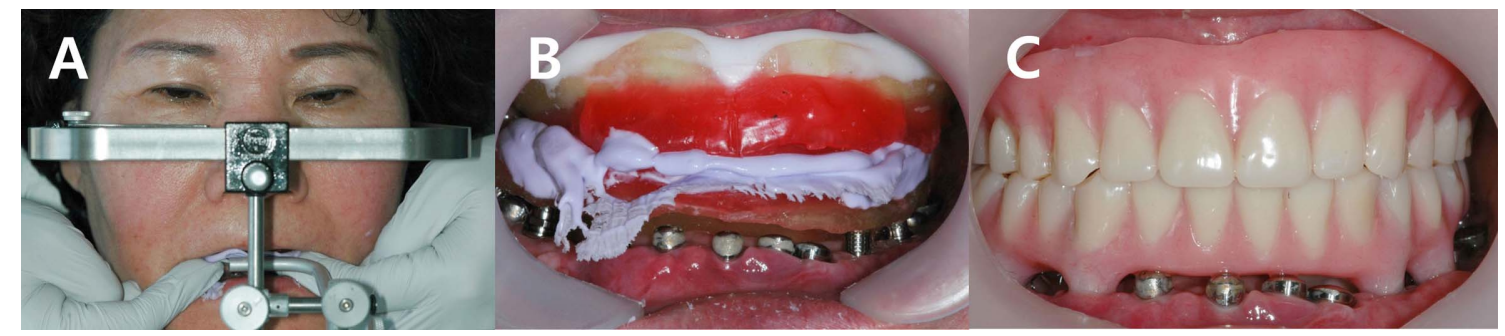

Fig. 6. (A) Face-bow transfer, (B) Jaw relation registration, (C) Provisional restoration. 


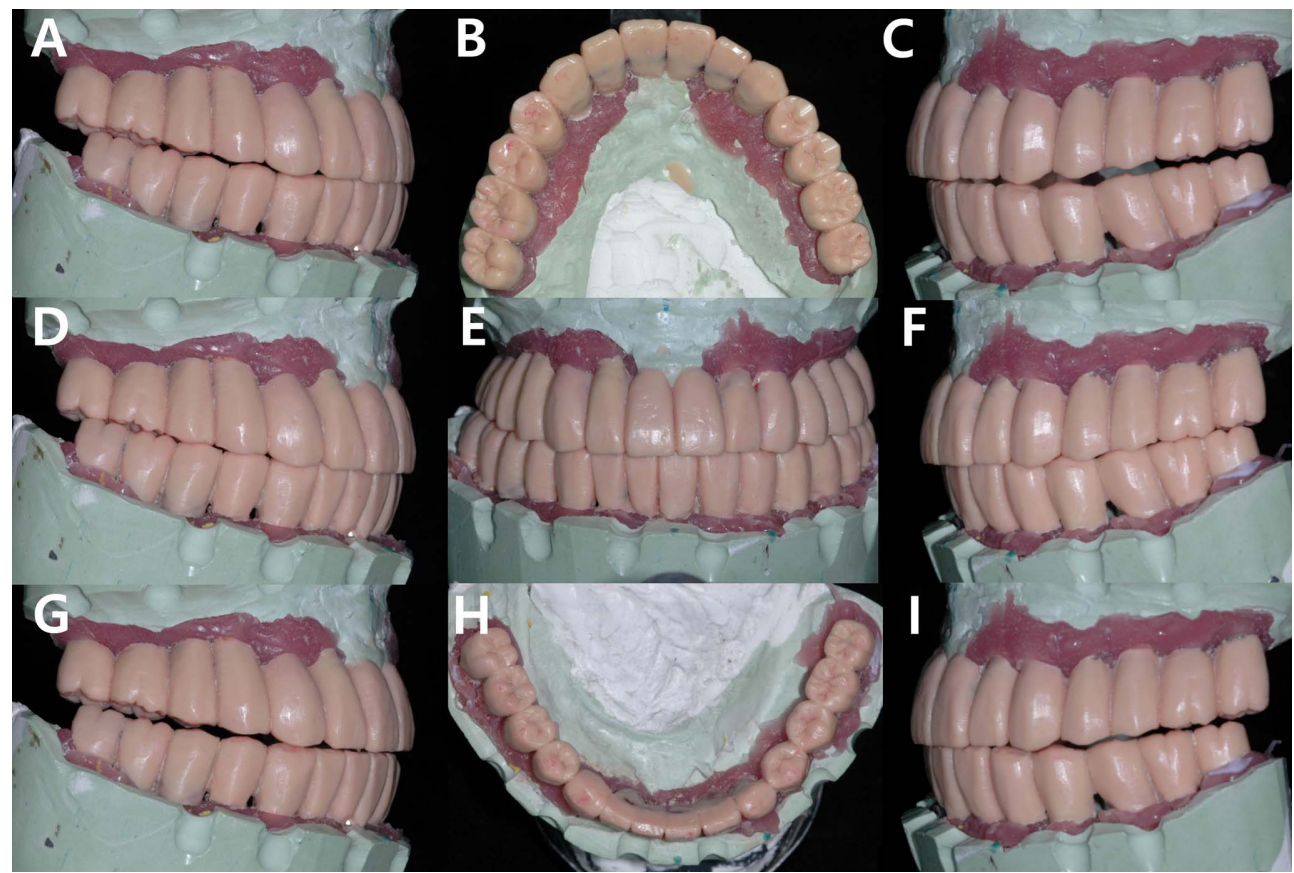

Fig. 7. (A) Balancing side during left lateral excursion, (B) Maxillary occlusal view, (C) Working side during left lateral excursion, (D) Right buccal view during centric occlusion, (E) Frontal view during centric occlusion, (F) Left buccal view during centric occlusion, (G) Working side during right lateral excursion, $(\mathrm{H})$ Mandibular occlusal view, (I) Balancing side during right lateral excursion.

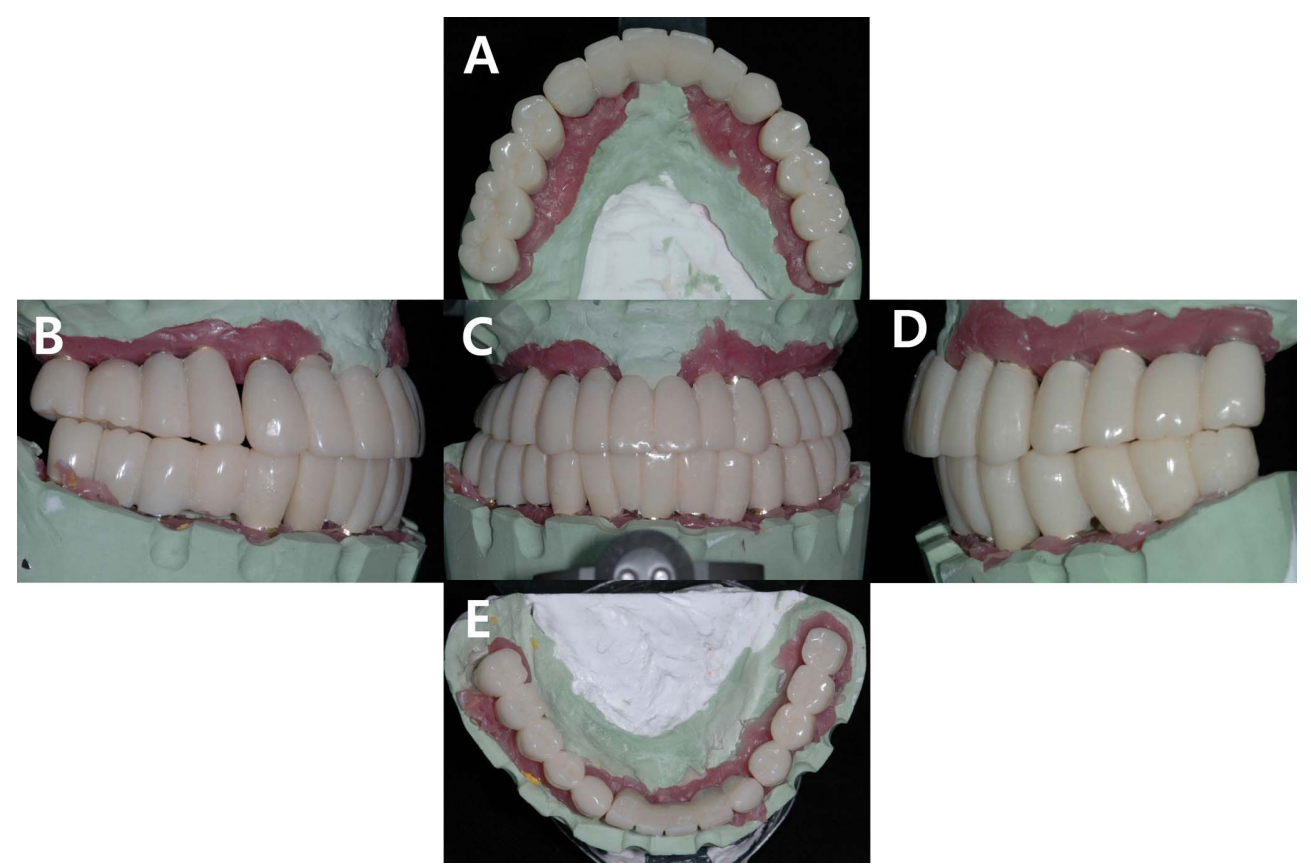

Fig. 8. Provisional restoration with CAD/CAM customized abutment and PMMA block. (A) Maxillary occlusal view, (B) Right buccal view during centric occlusion, (C) Frontal view during centric occlusion, (D) Left buccal view during centric occlusion, (E) Mandibular occlusal view.

\section{고 찰}

이상적인 치료계획을 위해 적절한 임플란트 지지를 얻 기 위한 우선적인 기준은 가용골의 양이다. 가용골의 너비,
높이, 길이, 그리고 각도 등을 평가하며, 골의 양이 계획된 보철물을 지지하기에 부족하다면 골이식이 고려된다. 자 가골 이식을 위한 공여부는 많은 골조직을 얻기에는 한계 가 있지만 구강내 공여부인 하악 이부, 하악지, 상악결절 등이 있고, 비교적 많은 양의 골조직을 얻을 수 있는 장골 
Hyeran Kim et al.

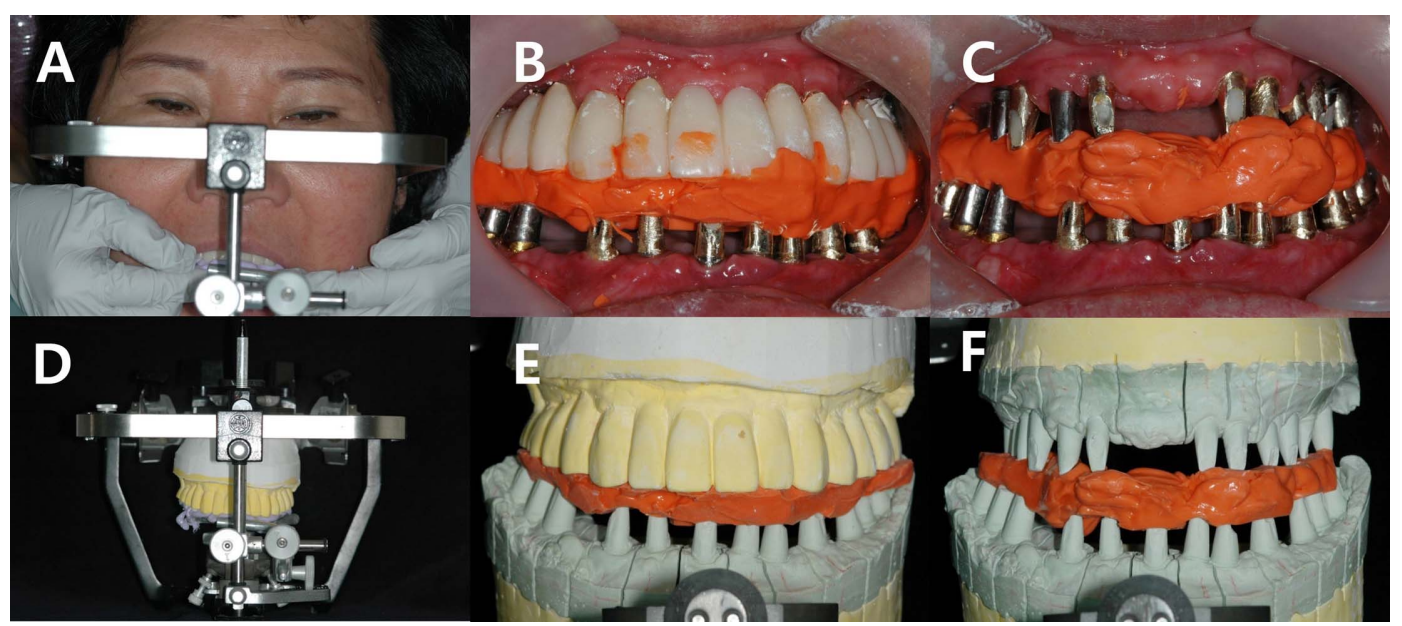

Fig. 9. (A) Face-bow transfer, (B) and (C) J aw relation registration for cross mounting, (D) Mounting maxillary cast with the face-bow, (E) and (F) Cross mounting of casts.

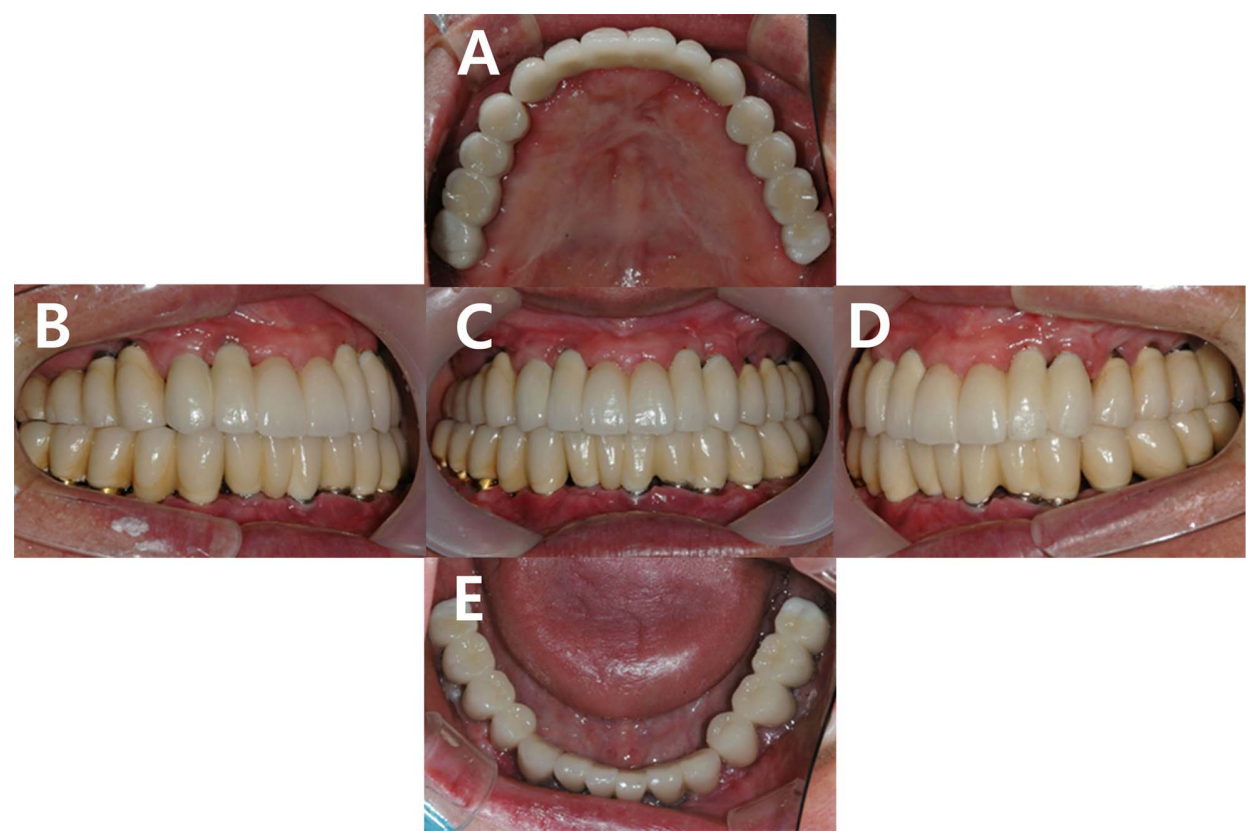

Fig. 10. Intraoral photo with definitive restoration. (A) Maxillary occlusal view, (B) Right buccal view during centric occlusion, (C) Frontal view during centric occlusion, (D) Left buccal view during centric occlusion, (E) Mandibular occlusal view.

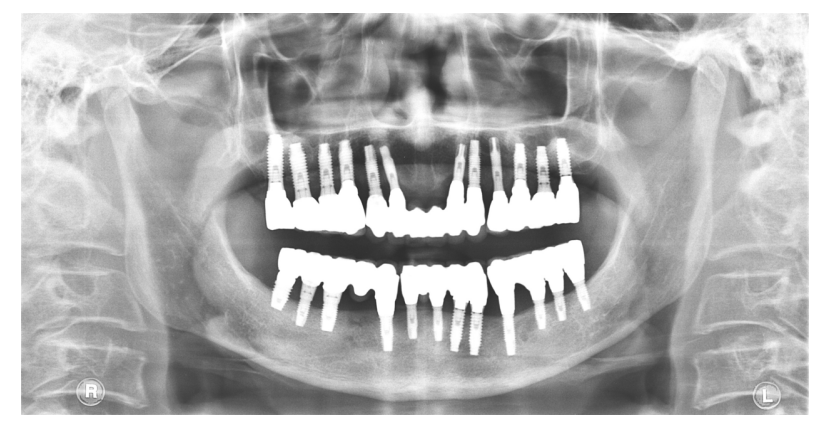

Fig. 11. Panoramic view with definitive restoration.

(ilium), 경골(tibia), 늑골(rib)과 같은 구강외 부위가 있다. 이 중에서도 장골은 많은 양의 골 채취가 가능하고, 피질
골과 해면골을 함께 채취할 수가 있으며, 공여부의 합병증 발생이 적고, 악골과 골질이 유사 하기 때문에 자가골 블 록 이식 시 널리 사용된다[7]. 이식편이 치유되면 임플란 트를 식립 하게 되는데 임플란트를 식립 하기 전에 이식 편 유합을 위해서는 충분한 치유과정이 필요하며, 또한 임 플란트 식립을 통해 신생골을 자극, 유지시켜야 하므로 너 무 늦어서도 안된다[8]. 장골 이식 후 임플란트를 식립 하 기까지 약 4개월 동안 치유기간을 갖는 것이 좋다[9]. 치 조골 재건에 있어 골이식시 이식골의 흡수나 노출, 감염 등의 합병증이 발생할 수 있으며, 연조직의 부족으로 골 이식재를 봉합하기 어려울 수 있다. Misch 등에 의하면 자 가 장골 이식시 4 개월 후 골 흡수량이 약 $40.4 \%$ 였다고 
하였다[10]. 따라서 원하는 치조골 높이를 얻기 위해서는 이식골의 흡수를 고려하여 목표하는 골 증대량의 30 40\% 정도 과증대 하는 것이 바람직하다. 또한 골조직뿐만 아니 라 연조직의 재생을 유도하는 장점이 있는 골 신장술과 전 정 성형술 등을 동반하는 것은 많은 양의 골 증가를 위한 좋은 보조요법이다. 연조직으로부터 혈류 공급을 받을 수 있기 때문에 염증이나 골 흡수에 대한 저항력이 신장된다 는 장점도 있다.

본 증례에서는 임플란트 식립시 하치조신경에 외상성 신경종이 생긴 환자에서 원인이 되는 임플란트를 제거하 고, 자가장골이식과 전정성형술 및 치근단변위판막술을 시행한 후 이상적인 교합평면, 중심위, 수직고경 설정 및 견치유도교합을 부여하여 전악 임플란트 보철 수복하고, 효과적인 치료를 위하여 구강내과 진료를 병행하였다. 환 자는 매1년마다 정기적으로 내원하여 유지관리 중이며, 통 증 개선 및 기능 심미부분에 만족해 하였기에 이를 보고 하는 바이다.

\section{Conflict of Interest}

The authors declare that they have no competing interests.

\section{ORCID}

$\begin{array}{ll}\text { Hyeran Kim } & 0000-0002-2992-5985 \\ \text { Jin-ho Shin } & 0000-0003-2072-0614 \\ \text { Hong-So Yang } & 0000-0002-6047-9733 \\ \text { Chan Park } & 0000-0000-5729-5127 \\ \text { Hyun-Pil Lim } & 0000-0001-5586-1404\end{array}$

\section{References}

1. Greenstein G, Marnow D. The mental foramen and nerve:clinical and anatomical factors related to dental implant placement: a literature review. J Periodontol 2006;77:1933-1943. doi: 10.1902/jop.2006.060197.

2. Misch CE, Crawford EA. Predictable mandibular nerve location-a clinical zone of safety. Int J Oral Implant 1990;7:37-40.

3. Ziccardi VB. Microsurgical techniques for repair of the inferior alveolar and lingual nerves. Atlas Oral Maxillofac Surg Clin North Am 2011;19:79-90.

4. Vernadakis AJ, Koch H, Mackinnon SE. Management of neuromas. Clin Plast Surg 2003 ;30:247-268. doi: http:// dx.doi.org/10.1016/S0094-1298(02)00104-9.

5. Hobo S. Twin-tables technique for occlusal rehabilitation: Part I-Mechanism of anterior guidance. J Prosthet Dent 1991;66:299-303. doi: http://dx.doi.org/10.1016/ 0022-3913(91)90253-S.

6. Hobo S. Twin-tables technique for occlusal rehabilitation: Part II-Clinical procedures. J Prosthet Dent 1991; 66:471-477. doi: http://dx.doi.org/10.1016/0022-3913(91) 90507-S.

7. Ryu SY, Kim IK, Kim JC, Oh HK, Park KW. Reconstruction of mandibular bone defect with autogenousiliac bone graft: Case reports and review of literature. J Korean Assoc Oral Maxillofac Surg 1986;12:65-74.

8. Nystrom E, Ahlqvist J, Kahnberg KE, Rosenquist JB. Autogenous onlay bone grafts fixed with screw implants for the treatment of severely resorbed maxillae. Radiographic evaluation of preoperative bone dimensions, postoperative bone loss, and changes in soft-tissue profile. Int J Oral Maxillofac Surg 1996;25:351-359. doi: http://dx.doi.org/10.1016/S0901-5027(06)80029-9.

9. Matsumoto MA, Filho HN, Francishone CE, Consolaro A. Microscopic analysis of reconstructed maxillary alveolar ridges using autogenous bone grafts from the chin and iliac crest. Int J Oral Maxillofac Implants 2002;17: 507-516.

10. Misch CM, Misch CE, Resnik RR, Ismail YH. Reconstruction of maxillary alveolar defects with mandibular symphysis grafts for dental implants: a preliminary procedural report. Int J Oral Maxillofac Implnats 1992;7: 360-366. 